\title{
Evaluation of the efficacy of levocarnitine in supporting therapy in multiple myeloma
}

\section{Ozoda ACHILOVA ${ }^{1}$, Gulchekhra MAKHAMADALIEVA ${ }^{2}$, Eldor ISKHAKOV ${ }^{3}$}

Republican Specialized Scientific Practical Medical Center of Hematology

Tashkent State Institute of Postgraduate Medical Education

\section{ARTICLE INFO}

\section{Article history:}

Received January 2021

Received in revised form

15 January 2021

Accepted 20 January 2021

Available online

01 February 2021

\section{Keywords:}

accompanying therapy,

levocarnitine,

toxicity assessment,

fortecarnitis,

metabolic correction.

\begin{abstract}
The accompanying therapy prescribed during the use of toxic drugs helps patients to complete the treatment to the end, and the doctor adheres to the treatment of the chosen line

The aim of the study was to study the effect of levocarnitine on blood biochemical parameters and on chemotherapy tolerance.
\end{abstract}

Materials and methods. The study was conducted in the stem cell treatment department at Republican Specialized Scientific Practical Medical Center of Hematology . Chemotherapy toxicity was assessed according to WHO and NCIC standards.

Results. In a comparative study, 30 patients receiving chemotherapy for myeloma with varying degrees of toxicity when fortecarnite (100 mg / kg / day) was added to standard therapy for 2 months or more showed a significant positive change in cytochemical parameters (Alanin transferase (ALT), aspartat transferase (AST)), which allowed the authors recommend metabolic correction to all patients receiving chemotherapy, especially with 2 nd and 3rd degree of toxicity.

2181-1415/C) 2021 in Science LLC.

This is an open access article under the Attribution 4.0 International (CC BY 4.0) license (https://creativecommons.org/licenses/by/4.0/deed.ru)

\footnotetext{
${ }^{1} \mathrm{PhD}$, hematologist of Republican Specialized Scientific Practical Medical Center of Hematology, Tashkent, Uzbekistan E-mail: sachilova@yahoo.com

2 PhD, hematologist of Republican Specialized Scientific Practical Medical Center of Hematology, Tashkent, Uzbekistan E-mail: kuzieva79@mail.ru

${ }^{3}$ Associate professor, DSc, Head of Department of «Hematology and Transfusiology», Tashkent State Institute of Postgraduate Medical Education, Ministry of Health of the Republic of Uzbekistan, Tashkent, Uzbekistan

E-mail: dr.eldor@yahoo.com
} 


\section{Levokarnitinni mieloma kasalligi bemorlarida yondosh terapiyada ahamiyatini baholash}

\section{Kalit so'zlar:}

qo'shma terapiya,

levokarnitin,

toksikani baholash,

fortekarnit,

metabolik tuzatish.

\section{ANNOTASIYA}

Toksik dorilarni qabul qilish paytida buyurilgan terapiya bemorlarga davolanishni yakunlashiga yordam beradi va shifokor davolanishni tanlangan yo'nalishda kuzatib boradi.

Tadqiqotning maqsadi levokarnitinning qonning biokimyoviy ko'rsatkichlari va kimyoviy terapiyaga bardoshliligi ta'sirini o'rganish edi.

Materiallar va uslublar. Respublika ixtisoslashtirilgan ilmiyamaliy gematologiya tibbiyot markazi klinikasida urganildi. Kimyoviy terapiyaning toksikligi JSST va NCIC standartlariga muvofiq baholandi.

Natijalar. Qiyosiy tadqiqotlar davomida mieloma uchun toksik darajasi har xil bo'lgan PCT bilan og'rigan 30 nafar bemorda 2 oy va undan ko'proq vaqt davomida fortekarnit (kuniga $100 \mathrm{mg} / \mathrm{kg}$ ) standart terapiyaga qo'shilganda sitokimyoviy parametrlarda (ALT, AST) sezilarli o'sish kuzatildi. Mualliflar kimyoviy terapiya qabul qiladigan barcha bemorlar uchun metabolik tuzatishni tavsiya etadilar, ayniqsa 2 va 3 darajali toksiklik bilan.

\section{Оценка эффективности левокарнитина сопроводительной терапии при множественной миеломе}

\footnotetext{
Ключевые слова:

Сопроводительная

терапия,

левокарнитин,

оценка токсичности,

фортекарнит,

метаболическая

коррекция.
}

\section{АННОТАЦИЯ}

Сопроводительная терапия, назначаемая при применении токсичных препаратов, во многом помогает пациентам довести лечение до конца, а врачу придерживаться терапии выбранной линии

Целью исследования явилось изучить влияние левокарнитина на биохимические показатели крови и на переносимость химиотерапии.

Материалы и методы. Исследование проводилось в отделении по лечению стволовыми клетками при центре Гематологии. Оценка токсичности химиотерапии проводилась - по стандартам BO3 и NCIC.

Результаты. В сравнительном исследовании у 30 пациентов, получающих ПХТ при миеломной болезни с различной степенью токсичности при добавлении к стандартной терапии фортекарнита (100 мг/кг/сутки) в течение 2 месяцев и более отмечено значимое положительное изменение цитохимических показателей (аланин трансфераза (АЛТ), аспартат трансфераза (АСТ)), что позволило авторам рекомендовать метаболическую коррекцию всем пациентам, получающим ПХТ, особенно при 2-й и 3-й степени токсичности. 
Concomitant therapy prescribed when using toxic drugs, in many ways helps patients to complete treatment, and the doctor to adhere to the therapy of the chosen line $[4,5]$. In the treatment of neurological, cardiological, nephrological diseases, the use of targeted medications is repeated many times until remission is achieved. Hematological and oncological diseases, all the more, are no exception $[7,10]$.

At present, when conducting PCT courses, great importance is attached to the issues of metabolic therapy as a significant pathogenetic link in almost all complications caused by chemotherapy $[1,2,7,10]$. In this regard, the search for drugs with a general effect on metabolism is relevant. One of these drugs is discovered by Russian scientists R. Krimberg and V.S. Gulevich, carnitine is a natural compound, the metabolic functions of which are associated with the transport of fatty acids into the mitochondria, where they are oxidized with the release of energy ATP, modulation of the intracellular homeostasis of coenzyme $A$ in the mitochondrial matrix, detoxification of excess acetic and a number of other organic acids, as well as participation in the process of glycolysis, exchange of ketone bodies and choline $[2,3,4,9]$. In the presence of carnitine, free radical binding reactions occur, which is manifested by a decrease in intoxication syndrome. Carnitine is found in all organs, especially in tissues that require high energy supply - muscles, myocardium, brain, liver, kidneys. The need for carnitine is individual (usually 200-500 mg per day for an adult), and with mental, physical and emotional stress, diseases and functionally special conditions (stress, pregnancy, breastfeeding, sports, etc.) 20 times. In patients receiving chemotherapy, the need for carnitine increases due to an increase in oxidation products in the body and an increase in the catabolic syndrome associated with the direct tumorlytic effect of cytostatics $[7,8,9]$. Endogenous synthesis in an adult provides only about $10 \%$ of the body's need for carnitine, and this requires vitamins C, B3, B6, folic acid, iron, a number of amino acids and enzymes. With a deficiency of at least one of the components, carnitine deficiency with its various systemic manifestations may develop. During chemotherapy, the endogenous synthesis of carnitine decreases, which makes them vulnerable to insufficient intake of exogenous carnitine from food, especially when there is a deficiency in the diet of animal protein $[1,2,4,7]$. Despite the widespread use of carnitine in medicine in the treatment of various diseases, the presented results of its use in correcting the side effects of chemotherapy are insufficient. The normal diet covers half of the carnitine requirement at best, so there is a clear need for additional sources of carnitine to meet optimal physiological requirements. The natural L-stereoisomer of carnitine is biologically active, therefore only L-carnitine, which is almost completely absorbed in the human gastrointestinal tract, should be used as a food additive or drug [4,9]. The domestic company "Rapid Solution" produces the drug "Fortecarnit" (INN LEVOCARNITINE) for oral administration, containing a $20 \%$ aqueous solution of L-carnitine, which is identical in chemical structure and biological activity to natural.

The aim of the study was to study the effect of levocarnitine on blood biochemical parameters and on the tolerance of chemotherapy.

\section{MATERIAL AND METHODS}

The study was carried out in the department for stem cell treatment at hematology center. The study involved 60 patients. The patients are divided into 2 groups of 30 people each. Age ranged from 33-59 years old (on average 42 years old), men - 27, women -33. Group 1 - 30 people who were prescribed standard concomitant therapy and levocarnitine 
at a dose of $100 \mathrm{mg} / \mathrm{kg} /$ day daily for 60 days. Group 2 - 30 people received standard concomitant therapy without levocarnitine. The assessment of the toxicity of chemotherapy was carried out according to the WHO and NCIC standards. Assessment of hematological toxicity was carried out according to the results of weekly examination of patients, as well as before each course of chemotherapy. Control of non-hematological toxicity was carried out immediately before the administration of drugs and in the intervals between courses of chemotherapy. At the start of chemotherapy, the patients had an overall ECOG functional status of 0 to 2 and a life expectancy of at least 6 weeks. All had satisfactory blood counts: neutrophils $\geq 1500 / \mathrm{mm} 3$, platelets $\geq 100,000 / \mathrm{mm} 3$, creatinine less than $200 \mu \mathrm{mol} / \mathrm{l}$, hemoglobin more than $80 \mathrm{~g} / \mathrm{l}$, there were no concomitant diseases in the stage of decompensation.

\section{RESULTS AND DISCUSSION}

The therapeutic effect was considered in 60 patients who received 135 courses of chemotherapy. On average, 2 courses of chemotherapy per person. In a comparative analysis of the toxicity of chemotherapy, nausea and vomiting were most often observed, more in the group of patients treated without levocarnitine. In $2(6 \%)$ cases, due to vomiting, the chemotherapy course had to be postponed for 1 week.

Leukopenia was also more often observed in group 2, 9 (18\%) patients were prescribed colony-stimulating factors, in $3(6 \%)$ the dose of cyclophosphamide was reduced by $20 \%$, the timing of chemotherapy did not change. The frequency and degree of fever were more pronounced, and in $3(10 \%)$ patients, chemotherapy was delayed by 1 week, and they received appropriate antibiotic therapy for the infectious syndrome. Grade IV neutropenia occurred in 5 patients (18\%), which led to the complete cancellation of the target drug and its replacement with a second-line drug. Among other types of toxicity, cystitis was observed in group 2 - in $2(6.0 \%)$ patients who underwent symptomatic treatment, the timing of chemotherapy did not change, and cardiotoxicity - in 1 (3\%) patient, the dose of borezomib was reduced by $30 \%$. In the compared group, no such phenomena were registered (Table 1).

The use of levocarnitine at a dose of $100 \mathrm{mg} / \mathrm{kg}$ / day reduced dyspeptic complaints in patients by $30 \%$. In the 2nd group, polychemotherapy courses did not have to be postponed. The length of hospital stay decreased by 3-4 days. In addition, in patients of group 1, with the introduction of chemotherapy drugs, an increase in ALT and AST was never recorded. On the contrary, in patients of the 2nd group, in all cases, there is a transient increase in ALT (47-52 U / L) and AST (51-61 U / L) in 15 patients (50\%), and a persistent increase in enzymes of more than $60 \mathrm{U} / \mathrm{L}$ in 5 (20\%).

Table 1.

Comparative assessment of the toxicity of chemotherapy in groups 1 and 2.Tab

\begin{tabular}{|l|l|l|l|l|l|l|l|l|}
\hline \multirow{2}{*}{ Toxicity type } & \multicolumn{9}{l}{ Toxicity level according to WHO criteria } \\
\cline { 2 - 12 } & I & \multicolumn{2}{l|}{ II } & \multicolumn{1}{l|}{ III } & \multicolumn{2}{l|}{ IV } \\
\hline Nausea & 12 & 19 & 4 & 5 & 1 & 2 & - & 1 \\
\hline Vomiting & 5 & 12 & 2 & 3 & 1 & 1 & - & - \\
\hline Leukopenia & 1 & 3 & - & 1 & - & 1 & - & - \\
\hline Stomatitis & - & 2 & - & 2 & - & - & - & - \\
\hline
\end{tabular}




\begin{tabular}{|l|l|l|l|l|l|l|l|l|}
\hline Anemia & - & 14 & - & 4 & - & 2 & - & - \\
\hline Thrombocytopenia & - & 1 & - & - & - & - & - & - \\
\hline Neutropenia & - & & - & - & - & - & - & - \\
\hline Neuropathy & 5 & 15 & - & - & - & - & - & - \\
\hline Cystitis & - & 2 & - & - & - & - & - & - \\
\hline Cardiotoxicity & - & 1 & - & - & - & - & - & - \\
\hline
\end{tabular}

The patient's physical health and the degree of his quality of life were assessed by a questionnaire based on the OPCW questionnaire. When questioning, it was found that a group of patients receiving planned chemotherapy with the use of high doses of dexamethasone, who received Fortecarnit at $100 \mathrm{mg} / \mathrm{kg} /$ day for 60-75 days as part of concomitant therapy, showed an improvement in physical condition by 1.6 times compared with the control group ...

Conclusion. In a comparative study, in 30 patients receiving PCT for multiple myeloma with varying degrees of toxicity, when added to standard therapy fortecarnite (100 mg / kg / day) for 2 months or more, a significant positive change in cytochemical parameters (ALT, AST) was noted, which allowed the authors recommend metabolic correction to all patients receiving chemotherapy, especially with the 2nd and 3rd degree of toxicity. In addition, the addition of levocarnitine to concomitant therapy can reduce complications after chemotherapy, improve drug tolerance and dyspeptic complaints.

\section{References:}

1. Dmitrieva N.V., Petukhova I.N. Rational approaches to the treatment of febrile neutropenia in cancer patients. - M .: Borges, 2003 .- 73 p.

2. Smoke S.V., Derbeneva N.A., Renke A.L. Treatment of infectious complications in pediatric patients with neutropenia induced by previous cytostatic therapy. Local protocol 2009

3. Maschan A.A., Rumyantsev A.G. Hematopoietic stem cell transplantation in children. - M .: Medical Information Agency, 2003. - 325 p.

4. Orlova R.V., Moiseenko V.M. Principles of drug treatment for patients with disseminated breast cancer // Practical Oncology. 2000. No. 2. P.19-21.

5. Orlova R.V., Chubenko V.A. Febrile neutropenia. Infectious toxic shock // Practical Oncology. - 2006. - T. 7, No. 2. - S. 69-76.

6. Translator N.I. The place of chemotherapy in the system of treatment of cancer patients and the choice of therapeutic tactics // Modern Oncology. 2001. T. 3, No. 2. Translator N.I. A guide to the chemotherapy of neoplastic diseases. M., 2005. S. 254-267.

7. Ptushkin V.V. Treatment and prevention of chemoradiation treatment in patients with lymphomas // Practical Oncology. - 2004. - T. 5, No. 3. - S. 223-230.

8. Rumyantsev A.G., Maschan A.A., Samochatova E.V. Concomitant therapy and control of infections in hematological and oncological diseases. - M .: Medpraktika-M, 2006 --- 235 p.

9. Stetsyuk I.V., Donskaya S.B., Ryzhak O.A. Treatment of infectious complications in pediatric patients with neutropenia induced by previous cytostatic therapy. - Kiev, 2002 -- $413 \mathrm{p}$.

10. Tets V.V. Microorganisms and antibiotics. Sepsis. - SPb .: Eskulap, 2003 --- 154 p.

11. Cometta A., Kern W.V., De Bock R. et al. Vancomycin versus placebo for treating persistent fever in patients with neutropenic cancer receiving piperacillin-tazobactam monotherapy // CID. — 2003. - № 37. - P. 382-389. 
12. Haematopoietic Stem Cell Transplantation. The EBMT Handbook / Ed. by J. Apperley, E. Carreras, E. Gluckman, A. Gratwohl, T. Masszi. - 2008. - 356 p.

13. Hughes W.T., Armstrong D., Bodey G.P. et al. Guidelines for the use of antimicrobial agents in neutropenic patients with cancer // CID. - 2002. - Vol. 34. - P. 730-751.

14. Klastersky J., Paesmans M., Rubenstein E.B. The Multinational Association for Supportive Care in Cancer Risk Index: A Multinational Scoring System for Identifying Low-Risk Febrile Neutropenic Cancer Patients // JCO. — 2000. — Vol. 18. — P. 3038-3051.

15. Lin S., Schranz J., Teutsch S.M. Aspergillosis case-fatality rate // CID. - 2001. - Vol. 32. - P. 358-366. 13. Pizzo P.A., Robichaud K.J., Gill F.A. et al. Empiric antibiotic and antifungal therapy for cancer patients with prolonged fever and granulocytopenia // Amer. J. Med. — 1992. - Vol. 72. - P. 101-111.

16. Trillet-Lenoir V., Green J., Manegold C. et al. Recombinant granulocyte colony stimulating factor reduces the infectious complications of cytotoxic chemotherapy // Europ. J. Cancer. - 2009. - Vol. 29A. - P. 319-322. 